\title{
PELAKU PEMBUNUHAN YANG MEMBELA DIRI DALAM MEMPERTAHANKAN KEHORMATAN DAN HARTA BENDA
}

\author{
MARSUDI UTAYO
}

Dosen Tetap Persyarikatan

Sekolah Tinggi Ilmu Hukum Sumpah Pemuda Palembang

\begin{abstract}
ABSTRAC
Article 49 paragraph (1) of the Criminal Code regulates the actions "emergency defense" (noodweer) for themselves and for others, decency, honor or property themselves or others, because there is an attack or threat of attack is very close. According to this article people who do defense emergency can not be punished. Factors That Makes Working Out Perpetrators of Criminal Punishment by Penal Code are: Ontoerekenings-vatbaarheid (an inability responsible), Overmacht (necessity) forced or emergency, Noodweer (urgent advocacy), Wettelijk voorschrif (command laws), bevel Ambtelijk (command term)
\end{abstract}

Keywords: Overmacht, Noodweer, command laws, command term

\section{PENDAHULUAN}

Bahwa manusia dianugrahi oleh Tuhan Yang Maha Esa akal budi dan nurani yang memberikan kepadanya kemampuan untuk membedakan mana yang baik dan buruk, serta akan dapat membimbing juga mengarahkan sikap dan perilaku dalam menjalani kehidupannya. Dengan akal budi dan nurani, maka manusia memiliki kebebasan untuk memutuskan sendiri perilaku atau perbuatannya. Disamping itu, untuk mengimbangi kebebasan tersebut manusia memiliki kemampuan untuk bertanggung jawab atas semua tindakan yang dilakukannya. $^{1}$

Kitab Undang-undang Hukum Pidana (KUHP) adalah sumber pokok hukum pidana materiil, yang memuat tentang aturan hukum pidana dan rumusan-rumusan tindak pidana tertentu, mengenai aturan umum dimuat dalam

*Marsudi Utoyo, Dosen Persyarikatan, SEKOLAH TINGGI ILMU HUKUM SUMPAH PEMUDA Palembang.

1 Pustaka Yustisia, Penjelasan Undangundang RI No. 39 Tahun 1999 Tentang HAM, Pustaka Yustisia, Yogyakarta, 2006, hlm 76. buku I, buku II mengatur tentang kejahatan dan buku III adalah tentang pelanggaran. Dalam buku II KUHP ini mengatur tentang perbuatan-perbuatan tertentu yang dilarang untuk dilakukan orang yang disertai ancaman pidana tertentu bagi siapa yang melakukan perbuatan yang menjadi larangan tersebut.

Aturan umum memuat asas-asas umum mengenai berbagai hal atau bidang dalam hukum pidana, misalnya batas-batas berlakunya hukum pidana, tentang pidana dan hal-hal yang meniadakan, mengurangi serta memberatkan pidana, tentang pembarengan, tentang percobaan, tentang penyertaan dan lain sebagainya. Aturan umum hukum pidana ini berlaku tidak saja tindak pidana, melainkan juga terhadap tindak pidana yang ada diluar KUHP sepanjang dalam Undang-undang lain itu tidak ditentukan lain (Pasal 103).

Sejak dahulu kala sampai sekarang sarjana hukum saling bertengkar mengenai soal, mengapa suatu kejahatan harus ditanggapi dengan suatu pidana. ${ }^{2}$ Antara

\footnotetext{
${ }^{2}$ Wirjono Prodjodikoro, Asas-asas Hukum Pidana di Indonesia, PT Eresco, Bandung, 1986, hlm 13
} 
pidana dan kejahatan merupakan suatu rangkaian yang tidak dapat dipisahkan yaitu perbuatan dan sanksi, yang merupakan adanya perbuatan akan dikenakan sanksi, bahwa dasar pokok dalam menjatuhi pidana pada orang yang telah melakukan perbuatan pidana adalah norma yang tidak tertulis, tidak dipidana jika tidak ada kesalahan. Dasar ini adalah mengenai dipertanggung jawabkannya seseorang atas perbuatan yang telah dilakukannya. Jadi mengenai criminal responsibility atau criminal liability, azas yang menentukan bahwa tidak ada perbuatan yang dilarang dan diancam dengan pidana jika tidak ditentukan terlebih dahulu dalam perundangundangan. Biasanya ini dikenal dalam bahasa latin sebagai "Nullum delictum nulla poena sine praevia lege poenali" ? yang dikenal dengan azas legalitas, biasanya asas legalitas ini dimaksud mengandung tiga pengertian, yaitu :

1. Tidak ada perbuatan yang dilarang dan diancam dengan pidana kalau hal itu terlebih dahulu belum dinyatakan dalam suatu aturan undang-undang.

2. Untuk menentukan adanya perbuatan pidana tidak boleh digunakan analogi.

3. Aturan-aturan hukum pidana tidak berlaku surut. ${ }^{4}$

Hukum pidana merupakan ultimum remedium, yaitu upaya terakhir guna memperbaiki tingkah laku manusia terutama penjahat, serta memberikan tekanan psikologis agar orang-orang lain tidak melakukan kejahatan. ${ }^{5}$

Apa yang kini dinamakan "kejahatan" adalah pelanggaran dari norma-norma sebagai unsur pokok kesatu dari hukum pidana dan inilah yang disebut dengan istilah perbuatan melanggar hukum. Umur kejahatan itu sama

\footnotetext{
${ }^{3}$ Moeljatno, Asas-asas Hukum Pidana,

Penerbit Rineka Cipta, Jakarta, 2002, hlm 23

${ }^{4}$ Ibid, hlm 25

5 Andi Zainal Abidin, Asas-asas Hukum

Pidana Bagian Pertama, Penerbit Alumni, Bandung, 1987, hlm 16
}

panjangnya dengan umur umat manusia itu sendiri, bahkan ada ungkapan yang menyatakan "dimana ada manusia di sana ada kejahatan", kejahatan adalah sahabat setia umat manusia, dia hadir sebagai penyimpangan perilaku dalam masyarakat, kejahatan bisa hadir kapanpun dan diamanapun manusia berada, maka dari itu tingkat dan jenis kejahatan itu dapat beradaptasi dengan dinamika yang terjadi dalam masyarakat itu sendiri. Oleh karena itu maka hadirlah "hukum", hukum hadir bukan semata-mata menjadi pe ngekang manusia akan kebebasannya, namun juga menjadi cambuk untuk menindak perilaku yang berbahaya yang dilakukan manusia, dengan harapan tidak akan terulang kembali.

Kata-kata "kejahatan" adalah terjemahan dari bahasa Belanda sebagai terjemahan dari istilah-istilah (misdrijf) atau "kejahatan" berarti suatu perbuatan yang tercela dan berhubungan dengan hukum, berarti tidak lain daripada "perbuatan melanggar hukum" 6 .

Didalam penjelasan Undang-undang dasar 1945 menjelaskan dengan tegas, bahwa negara Indonesia berdasarkan atas hukum (Rechtstaat) tidak berdasarkan atas kekuasaan (machstaat). ${ }^{7}$ Hal ini berarti bahwa Indonesia ialah negara hukum yang demokratis berdasarkan Pancasila dan Undang-undang Dasar 1945, menjunjung tinggi hak asasi manusia dan menjamin semua warga negara mempunyai kedudukan yang sama dihadapan hukum, serta wajib menjunjung hukum dan pemerintah dengan tidak ada pengecualian.

Sebagai negara hukum, terdapat ciriciri (rule of law) khas yang layak disebut negara hukum, ciri-ciri tersebut antara lain

1. Pengakuan dan perlindungan atas hakasasi manusia

\footnotetext{
${ }^{6}$ Wirjono Prodjodikoro, Asas-asas Hukum
} Pidana di Indonesia, PT. Eresco, Bandung, 1986, hlm 30

${ }^{7}$ Ibid, hlm 67 
2. Peradilan yang bebas dari pengaruhsuatu kekuatan atau kekuatan lain dan tidak memihak.

3. Legalitas dalam arti hukum dalam segala bentuknya.

Dari ketentuan diatas, dapat diketahui bahwa setiap orang berhak untuk memperoleh jaminan agar hukum dan negara harus dilaksanakan dengan adil dan jujur serta tidak meninggalkan perasaan hormat akan harkat dan martabat manusia. Sesungguhnya hukum dan undang-undang itu sendiri sudah menjamin agar hak-hak asasi manusia tidak dilanggar dan walaupun tidak sepenuhnya diatur akan tetapi tidak berarti negara dapat berlaku sewenang-wenang, sebab hak asasi manusia itu sudah ada sejak manusia lahir, hal ini dapat dilihat dalam pasal 1 pernyataan umum hak asasi manusia (Universal Declaration of Human Right) yang menyatakan bahwa: "sekalian umat manusia dilahirkan merdeka dan sama dalam martabat dan hak-haknya".

Tindak pidana biasanya dilandasi dengan berbagai motif maupun rencana, mulai dari sakit hati, cemburu, dendam, hutang piutang dan lain sebagainya, tidak mengendurkan niatnya untuk melakukan kejahatan dan ini sebagai indikasi semakin meningkatnya kejahatan terhadap nyawa ini khususnya dalam kasus pembunuhan berencana. Adapun perencanaan terlebih dahulu dimaksudkan untuk, pelaku memiliki rencana yang matang, pelaku memilih waktu yang tepat, dan pelaku dapat melaksanakan niatnya itu secara tenang. Bukan kerane terpaksa atau keadaan yang memaksa.

Sebagai contoh daya relatif atau (nisbi); relatieve overmacht. Kekuasaan, kekuatan, dorongan atau paksaan pisik atau psychicsh terhadap orang bersangkutan bersifat relatif atau nisbi. Misalnya pada perampokan sebuah bank, karyawan bank diancam dengan pistol supaya menyerahkan uang. Bilamana tidak dilakukannnya maka pistol itu akan ditembakkan oleh perampok dan akan mengancam nyawa karyawan bank tersebut. Teoritis karyawan bank itu dapat melawan dengan resiko mati terkena tembakan perampok. Bilamana ia tidak melawan dan menuruti kehendak perampok, maka ia tidak dapat dipidana, sekalipun ia telah mewujudkan delik. Menurut Jonkers orang yang diancam, dipaksa atau didoronglah yang berbuat, sekalipun ia berbuat karena ancaman atau dorongan itu. Tidak semua paksaan atau dorongan terhadap seseorang dapat menimbulkan relatieve overmacht. Kekuatan, paksaan atau dorongan itu haruslah sedemikian rupa sehingga orang yang terkena tidak dapat atau tidak perlu mengadakan perlawanan ${ }^{8}$.

Dalam pembelaan darurat atau noodweer artinya "pembelaan darurat". Supaya orang mengatakan bahwa dirinya dalam "pembelaan darurat" dan tidak dapat dihukum". Karena adanya syarat bahwa serangan itu harus seketika itu juga mengancam, maka pembelaan terpaksa tidak boleh dilakukan dalam ${ }^{10}$ :

a. hal, bahwa serangan yang mengancam itu akan terjadi dikemudian hari,

b. hal, bahwa serangan itu telah selesai.

Menurut van Bemmelen, bahwa perbuatan pada noodweerxses adalah melawan hukum; dengan kata lain terhadap perbuatan itu tetap dipidana, hanya terhadap pembuat tidak terdapat verwijt. Kalau ditinjau dari segi ajaran atau pandangan monistis tentang delik, maka dalam hal adanya noodweer, perbuatan itu dianggap tidak memenuhi unsur melawan hukum, sedangkan pada noodweerexes, perbuatan pidana tetap ada, tetapi unsur

${ }^{8}$ Andi Zainal Abidin, Asas-asas Hukum Pidana Bagian Pertama, Alumni, Bandung, 1987, hlm 227-228.

R. Soesilo, Kitab Undang-Undang Hukum Pidana (KUHP) serta Komentarkomentarnya Lengkap Pasal Demi Pasal, Politea, Bogor, 1993, hlm 64-66.

${ }^{10}$ Loc Cit, hlm 237-237. 
bertanggungjawab pidana, yakni kesalahan pembuat terhapus.

Secara ringkas dan sederhana pembelaan terpaksa dan perlampuan pembelaan terpaksa dapat dibedakan sebagai berikut: Noodweer ialah pembelaan yang diberikan karena sangat mendesak terhadap penyerangan yang mendadak dan tiba-tiba serta mengancam dan melawan hukum. Unsur-unsurnya ialah :

a. penyerangan yang nyata-nyata:

1. melawan hukum

2. mendesak dan sekonyongkonyong mengancam.

b. penyerangan itu harus mengenai :

1. badan (lijf) sendiri atau orang lain

2. kehormatan kesusilaan (eerbaarheid)

3. atau barang (goed) yang diserang atau orang lain

Noodweerexes ialah perlampuan batas pembelaan terpaksa, yang disebabkan suatu tekanan jiwa yang hebat karena adanya serangan orang lain yang mengancam. Dengan demikian pembelaan itu harus membela diri atau orang lain dan melindungi harta benda dan kesusilaan dalam keadaan terpaksa.

\section{PEMBAHASAN}

\section{Tanggung Jawab Pelaku Pembunuh an Dalam Membela Diri Untuk Mempertahankan Kehormatan Dan Harta Bendanya.}

Perbuatan pidana hanya menunjuk kepada dilarang dan diancamnya perbuatan dengan suatu pidana. Apakah orang yang melakukan perbuatan kemudian juga dijatuhi pidana, sebagaimana telah diancamkan, ini tergantung dari soal apakah dalam melakukan perbuatan ini dia mempunyai kesalahan. Sebab azas dalam pertanggungjawaban dalam hukum pidana ialah: tidak dipidana jika tidak ada kesalahan (Geen straf zonder schuld; Actus non facit reum nisi mens sir rea).
Azas ini tidak tersebut dalam hukum tertulis tapi dalam hukum yang tidak tertulis yang juga di Indonesia berlaku ${ }^{11}$.

Kejahatan terhadap jiwa seseorang diatur dalam BAB XIX buku II KUHP. Bentuk yang pokok dari kejahatan ini adalah pembunuhan (doodslag) yaitu menghilangkan jiwa seseorang. Dalam kejahatan tidak dirumuskan perbuatannya, tetapi hanya akibat dari perbuatannya yaitu hilangnya jiwa seseorang. Hilangnya jiwa ini timbul akibat perbuatan itu, tidak perlu terjadi segera, tetapi dapat timbul kemudian misalnya setelah dirawat dirumah sakit. Untuk dapat dikatakan menghilangkan jiwa, seseorang harus melakukan suatu perbuatan yang dapat menimbulkan akibat hilangnya jiwa ${ }^{12}$.

Dalam contoh kasus pembelaan diri dalam mempertahankan kehormatan dan harta benda baik milik sendiri maupun orang lain penulis mengutip berita dari koran Sumatera Ekspres seperti dibawah ini.

\section{Sopir Pemberani Yang Melawan dan Menewaskan 2 Perampok Mendapat Penghargaan dan Pantas Menjadi Pahlawan ${ }^{13}$.}

Palembang, 22 Maret 2009

Kepala Kepolisian Daerah Sumatera Selatan Inspektur Jenderal Sisno Adiwinoto memberikan penghargaan kepada Sulaiman (38), sopir yang menabrak dua perampok hingga tewas (Kompas, 21/3), atas keberaniannya melumpuhkan pelaku perampokan terhadap dirinya. Penghargaan diserahkan Kepala Bidang Humas Polda Sumsel Kombes Abdul Gofur, Sabtu (21/3) di RS

\footnotetext{
${ }^{11}$ Moeljatno, Op Cit, hlm 153

12 HAK. Moch. Anwar, hukum pidana bagian khusus (KUHP buku II), Alumni, Bandung, 1979, Hlm 88-89

13 Sumatera Ekspres, Sopir Pemberani Yang Melawan dan Menewaskan 2 Perampok Mendapat Penghargaan dan Pantas Menjadi Pahlawan, Palembang, Tangal 22 Maret 2009."
} 
Charitas, tempat Sulaiman menjalani perawatan.

Dua perampok berinisial JS (20) dan RH (31) menodongkan pistol lalu merampas tas plastik berisi uang $\mathrm{Rp} 130$ juta yang dibawa Sulaiman, sopir seorang pedagang karet. Perampok kemudian melarikan diri dengan sepeda motor BG 6367 UF. Sopir itu nekat memburu dan menabrak dua perampok hingga tewas dengan mobil di kompleks perumahan Poligon, Palembang, Jumat (20/3) siang. Mobil yang dikendarai Sulaiman terbalik setelah menabrak sehingga dia menderita luka serius di kepala.

Menurut Gofur, polisi akan melindungi sopir itu dan keluarganya. Dia juga berharap warga tidak hanya berani melawan pelaku kriminal, tetapi mencegah tindakan kejahatan dengan minta pengawalan polisi jika membawa uang dalam jumlah besar.

Kepala Poltabes Palembang Komisaris Besar Lucky Hermawan menyatakan, seorang pelaku, $\mathrm{RH}$, diduga juga terlibat dalam kasus pencurian dengan kekerasan lain.

Polisi menemukan barang bukti berupa dua paku yang ditancapkan pada potongan karet untuk mengempiskan ban mobil korban. Dengan demikian, pelaku kejahatan mudah mendekati korban yang terpaksa berhenti.

Menyinggung soal senjata yang digunakan, Lucky memastikan jenisnya revolver. Namun, saat ini sedang diperiksa di Laboratorium Forensik Mabes Polri untuk memastikan apakah senjata tersebut rakitan atau milik kepolisian RI

Pasal 49 ayat (1) KUHP mengatur mengenai perbuatan "pembelaan darurat" (noodweer) untuk diri sendiri maupun untuk orang lain, kehormatan kesusilaan atau harta benda sendiri maupun orang lain, karena ada serangan atau ancaman serangan yang sangat dekat. Menurut pasal ini orang yang melakukan pembelaan darurat tidak dapat dihukum. Pasal ini mengatur alasan penghapus pidana yaitu alasan pembenar karena perbuatan pembelaan darurat bukan perbuatan melawan hukum. Tentang Pasal 49 ayat (1) KUHP, R. Soesilo berkomentar antara lain bahwa supaya orang dapat mengatakan dirinya dalam "pembelaan darurat" dan tidak dapat dihukum harus dipenuhi tiga syarat::

(1) Perbuatan yang dilakukan itu harus terpaksa dilakukan untuk mempertahankan (membela). Pertahanan itu harus amat perlu, boleh dikatakan tidak ada jalan lain. Di sini harus ada keseimbangan yang tertentu antara pembelaan yang dilakukan dengan serangannya. Untuk membela kepentingan yang tidak berarti misalnya, orang tidak boleh membunuh atau melukai orang lain.

(2) Pembelaan atau pertahanan itu harus dilakukan hanya terhadap kepentingankepentingan yang disebut dalam pasal itu yaitu badan, kehormatan dan barang diri sendiri atau orang lain.

(3) Harus ada serangan yang melawan hak dan mengancam dengan sekonyongkonyong atau pada ketika itu juga.

Jika alasan penghapus pidana ini kemudian terbukti, maka hakim akan mengeluarkan putusan yang melepaskan terdakwa dari segala tuntutan hukum (ontslag van alle rechtsvervolging). Bukan putusan bebas alias vrijspraak. Jadi, hakimlah yang harus menguji dan memutuskan hal ini, sedangkan polisi hanya mengumpulkan bahan-bahannya untuk diajukan kepada hakim ${ }^{14}$.

Disini orang boleh melawan untuk mempertahankan diri dan barangnya yang dirampok itu, sebab perampok telah menyerang dengan melawan hak.

Faktor-faktor Yang Menjadikan Pelaku Pidana Terbebas dari Hukuman.

Pasal 49 (1) KUHP berbunyi : Barang siapa terpaksa melakukan perbuatan untuk pembelaan karena adanya

${ }^{14}$ R. Soesilo, Op Cit, hlm, 64-66. 
serangan atau ancaman serangan ketika itu yang melawan hukum terhadap diri sendiri maupun orang lain terhadap kehormatan kesusilaan (eerbaarheid) atau harta benda sendiri maupun orang lain, tidak dipidana. Kalimat ini kiranya masih dapat disingkat sebagai berikut : Barang siapa terpaksa melakukan pembelaan karena ada serangan atau ancaman serangan ketika itu yang melawan hukum terhadap diri, kehormatan kesusilaan (eenbaarheid) atau harta benda, baik kepunyaan sendiri maupun orang lain tidak di pidana ${ }^{15}$.

Yang menjadi soal pertama adalah bahwa perbuatan yang dimaksud dalam pasal 49 ayat 1 KUHP diatas, harus berupa pembelaan. Artinya lebih dahulu harus ada hal-hal memaksa terdakwa melakukan perbuatannya. Hal-hal itu dalam pasal tadi dirumuskan sebagai adanya serangan atau ancaman serangan. Jika demikian maka dalam kata "terpaksa pembelaan" ada termaktub 3 (tiga) pengertian yaitu:

a. harus berupa ada serangan atau ancaman serangan

b. harus ada jalan lain untuk menghalaukan serangan atau ancaman serangan pada sat itu dan;

c. perbuatan pembelaan harus seimbang dengan sifatnya serangan ancaman serangan.

Soal kedua adalah mengenai : kepentingan macam apa saja yang harus diserang sehingga dibolehkan pembelaan?. Ada 3 (tiga) hal yang masing-masing baik kepunyaan sendiri maupun kepunyaan orang lain yaitu ${ }^{16}$ :

a. diri atau badang orang

b. kehormatan, kesusilaan (eebaarheid)

Jonkers mengatakan bahwa ini adalah species dari a, artinya suatu kekhususan dari a, yang bertalian dengan seks. Beberapa penulis menyalin $b$ ini dengan kehormatan saja, hal mana salah benar. Sebagai contoh dari perbedaan antara serangan terhadap badan dengan

${ }^{15}$ Moeljatno, Op Cit, hlm 144

${ }^{16} \mathrm{Ibid}$, hal 146 serangan terhadap kehormatan kesusilaan, adalah demikian: meraba dada orang sesama kelamin kiranya tidak pantas kalau dibela dengan pukulan keras di atas kepala yang meraba. Sebab serangan terhadap diri orang yang demikian itu hanya bersifat ringan. Tapi kalau ada yang diraba dadanya tadi adalah berlainan kelamin, maka di situ ada serangan terhadap kehormatan kesusilaan yang bersifat serius juga, sehingga kemplangan (tamparan) keras di atas kepala tadi, adalah tindakan yang setimpal

c. Harta benda orang. Kiranya tentang hal ini tidak perlu komentar.

Soal yang ketiga adalah bahwa serangannya harus bersifat melawan hukum. Hanya terhadap gangguan yang melawan hukum, orang yang terkena mempunyai hak atau wewenang untuk mengadakan pembelaan.

Bagaimana kalau orang mengira ada serangan, atau mengira bahwa serangan itu melawan hukum padahal senyatanya tidak, dan mengadakan pembelaan menurut pasal 49 ayat 1 KUHP ?. Ini dinamakan pembelaan terpaksa yang putatif, yang hanya dalam pikirannya sendiri saja tapi sesungguhnya tidak ada. Bagi orang yang demikian itu tidak mungkin ada alasan pembenar. Perbuatannya tetap keliru. Hanya saja, pidana dapat dikurangi bahkan ditiadakan kalau "salah sangka" atau "salah terka" tadi, dapat dimengerti dan dapat diterima.

Menurut pasal 49 KUHP untuk dapat disebut (Noodweer) pembelaan mendesak harus memenuhi beberapa syarat yaitu ${ }^{17}$ :

1. Harus ada serangan

a. yang seketika (ogenblikkelijk).

b. mengancam secara langsung (ommiddelijk dreigend).

c. melawan hak.

2. Ada pembelaan:

a. sifatnya mendesak (noodzakelijk)

${ }^{17}$ Mustafa Abdullah dan Ruben Achmad, Op Cit, hlm 72. 
b. pembelaan itu menunjukan keseimbangan antara kepentingan hukum yang dilanggar dan kepentingan hukum yang dibela (geboden).

c. Kepentingan hukum yang dibela hanya, badan, kehormatan, harta sendiri maupun orang lain.

Faktor-faktor Yang Menjadikan Pelaku Pidana Terbebas dari Hukuman berdasarkan KUHP adalah :

a. Ontoerekeningsvatbaarheid (ketidak mampuan bertanggung jawab) pasal 44 KUHP, faktor yang membebaskan pelaku seperti ini karena pelaku jiwanya terganggu/sakit ingatan (gila).

b. Overmacht (keterpaksaan) pasal 48 KUHP, faktor terpaksa atau keadaan darurat karena pelaku terjepit diantara dua pilihan berebut baju pelampung dilaut untuk menyelamatkan nyawa dari tenggelam ${ }^{18}$.

c. Noodweer (pembelaan mendesak) pasal 49 KUHP, faktor membela harta benda kepunyaan sendiri atau kepunyaan orang lain, dari pada serangan yang melawan hukum dan yang berlaku sekejap itu atau yang mengancam dengan seketika. Pelaku membela kepentingan karena pembelaan terpaksa ${ }^{19}$.

d. Wettelijk voorschrif (perintah undangundang) pasal 50 KUHP, faktor pembebasan pidana karena pelaku diperintah oleh undang-undang dan yang diperintah (pelaku) melaksanakan dengan itikad baik yaitu melaksanakan tugas.

e. Ambtelijk bevel (perintah jabatan) pasal 51 KUHP, faktor pembebasan dari pidana pelaku mendapat perintah dengan wenang dan pelaksanaannya termasuk dalam lingkungan perkerjaan.

\section{PENUTUP}

\footnotetext{
${ }^{18}$ OpCit, Hal 140
}

${ }^{19}$ Ibid, hal 144
Berdasarkan uraian pada bab-bab sebelumnya terutama yang berhubungan dengan permasalahan, maka dapat ditarik suatu kesimpulan dan saran-saran sebagai berikut :

1. Pasal 49 ayat (1) KUHP mengatur mengenai perbuatan "pembelaan darurat" (noodweer) untuk diri sendiri maupun untuk orang lain, kehormatan kesusilaan atau harta benda sendiri maupun orang lain, karena ada serangan atau ancaman serangan yang sangat dekat. Menurut pasal ini orang yang melakukan pembelaan darurat tidak dapat dihukum.

2. Faktor-faktor Yang Menjadikan Pelaku Pidana Terbebas dari Hukuman berdasarkan KUHP adalah :

- Ontoerekenings-vatbaarheid (ketidak mampuan bertanggung jawab)

- Overmacht (keterpaksaan) terpaksa atau keadaan darurat.

- Noodweer (pembelaan mendesak).

- Wettelijk voorschrif (perintah undang-undang)

- Ambtelijk bevel (perintah jabatan)

\section{DAFTAR PUSTAKA}

Andi Zainal Abidin, Asas-asas Hukum Pidana Bagian Pertama, Alumni, Bandung, 1987.

Aruan Sakidjo dan Bambang Poernomo, Hukum Pidana, Dasar Aturan Umum, Hukum Pidana Kodifikasi, Ghalia Indonesia, Yogyakarta, 1990.

HAK. Moch. Anwar, hukum pidana bagian khusus (KUHP buku II), Alumni, Bandung, 1979.

Moeljatno, Asas-asas Hukum Pidana, Penerbit Rineka Cipta, Jakarta, 2002.

Mustafa Abdullah dan Ruben Achmad, Intisari Hukum Pidana, Ghalia Indonesia, Jakarta, 1986.

P.F. Lamintang, Dasar-dasar Hukum Pidana Indonesia, Alumni, Sumur Batu, Bandung. 
Pustaka Yustisia, Penjelasan Undangundang RI No. 39 Tahun 1999 Tentang HAM, Pustaka Yustisia, Yogyakarta.

R. Soesilo, Kitab Undang-Undang Hukum Pidana (KUHP) serta Komentarkomentarnya Lengkap Pasal Demi Pasal, Politea, Bogor, 1993.

Sumatera Ekspres, Sopir Pemberani Yang Melawan dan Menewaskan 2 Perampok Mendapat Penghargaan dan Pantas Menjadi Pahlawan, Palembang, Tangal 22 Maret 2009."

Wirjono Prodjodikoro, Asas-asas Hukum Pidana di Indonesia, PT Eresco, Bandung, 1986. 